\title{
NOTES ON THE LEAVES OF LIRIODENDRON.
}

\author{
BY \\ THEODOR HOLM, \\ Assistant in the Department of Botany.
}

(With Plates IV-IX.)

During the spring of 1889 , while engaged in studying the germination of some of our native plants, I collected quite a large number of germinating plantlets in the woods about Washington, especially along the Potomac shore. In the pursuit of these studies I found many specimens of our common Tulip-tree (Liriodendron Tulipifera), which, however, did not particularly attract my attention, since their germination with the cotyledons above ground showed nothing especially remarkable; nevertheless I collected a number of them and brought them home for closer examination. I now observed, that although their germination did not present anything of particular interest, they showed a peculiar fact in respect to their young foliage-leaves. The two or three leaves developed upon these young plants showed a great similarity among themselves, and at the same time differed from those of the older or full-grown tree. I then began the examination of the foliage of the mature tree, and it was not long before I observed that there was a certain regularity, depending upon the position of the different forms of leaves.

It is a well known fact that there is a great variation in the leaves of our recent Liriodendron, not ouly on the same tree, but even on the same branch, but as this circumstance does not seem to have been much discussed heretofore, it may be of interest, at least to paleobotanists, to describe the Liriodendron leaf somewhat carefully. After having collected many fine specimens of the leaves, from very young trees and from the branches of some of the oldest ones in the vicinity of Washington, I began to examine the course of the variation. First, however, I looked at the published descriptions of the tree, but it seems to be a fact so well known that the systematic authors have not thought it necessary to mention it. I consulted Prof. Lester F. Ward about it, but he did not remember where these variations were described by any author, but advised me to study certain paleobotanical publications, and called my attention especially to a paper by Dr. J. S. Newberry, 
entitled "The Ancestors of the Tulip-tree,"* and to several other papers important to this study.

If we wished to find a complete account of the variation of the leaves of Liriodendron Tulipifera, should we not seek it in a paper in which the author attempted to show its ancestral conditions? But I was disap. pointed in reading this paper, for, curiously enough, Dr. Newberry does not pay any considerable attention to the recent species. He enumer. ates and figures some new fossil species, and mentions, though briefly, some other ones described before, but the comparison with the living tree which I was looking for was entirely wanting. On turning to some other authors, for instance, Heer, Lesquereux, Saporta and others, I found descriptions and figures of fossil Liriodendron leaves, and I shall now try to give a comparison of these ancient types with the only living species, Liriodendron Tulipifera L.

The object of these notes, as will appear later, is to prove that, as far as is known to the author, there is not a greater difference in the foliage between many of the extinct species of Liriodendron than between a series of leaves from a very young tree or from a branch of an older one of our recent species. I shall therefore take as a point for discussion the last sentence in Dr. Newberry's paper: "Hence, until more material shall show the simple, ovate, or lanceolate forms to be connected by insensible gradations with others, I must regard them as specifically distinct."

The most rational manner of treating the question of the difference between the fossil and the recent species is to commence the examination with the living plant, of which the most complete material will be always at hand and certainly give the most reliable result. We have then to look at the descriptions given by the different authors in the systematic works. The species, as well as the genus, was first described by Linné in his "Species plantarum," 1764, p. 755, where he described the leaf as "tripartito aceris folio, media lacinia velut abscissa." It seems now, however, as if there is some disagreement among authors, who have either considered the leaf as three-lobed, with the middle lobe notched at its summit, or as a regular four-lobed leaf, but with the apex eut off. We shall see that of seventeen authors eight have described it as three-lobed, while the remaining nine have called it four-lobed. The different diagnoses of the leaf are as follows: "Foliis trilobis truncatis" Willdenow; $\dagger$ "leaves three-lobed, with the central lobe truncated" Nuttall ; $\ddagger$ "leaves truncate at the end, with two side lobes" Eaton;§ "leaves divided into three lobes, of which the middle one is horizontally notched at its summit and the two lower ones rounded at the base" Browne; " "leaves dilated, rounded or sub-

* Bulletin of the Torrey Botan. Club, vol. xıv, No. 1, 1E87.

† Willdenow: Species plantarum, vol. II, Pars II, p. 1254.

$\ddagger$ Ths. Nuttall: Genera of North American plants, 1818, p. 18.

$\oint$ A. Eaton: Manual of Botany for North America, 1833, p. 208.

|| D. I. Browne: The trees of America, 1846, p. 25 . 
cordate at base, usually three-lobed, the middle lobe broad and emarginately truncate" Darlington $;^{1}$ " leaves three-lobed, the middle lobe truncate, glabrous" Darby $;^{2}$ " the leaves are divided into three lobes, of which the middle one is horizontally notched at its summit and the two lower ones are rounded at the base" F. A. Michaux; "leaves angled, truncated, mostly rounded at the base, somewhat three-lobed, the middle lobe appearing as if cut off, leaving a shallow notch" Chapman. ${ }^{4}$ The leaf has also, as mentioned above, been described as fourlobed by following authors and in this manner: "Foliis abscisso-truncatis, quadri-lobatis" Michaux; ${ }^{5}$ the same diagnosis has been given by Pursh. 6 "Folia apice truncata, acute quadri-loba, lobis utrinque duobus sinu obtuso lato distinctis" de Candolle; "leaves cut truncate, four-lobed" Barton $;^{8}$ "leaves four lobed, truncate" Torrey $;^{3}$ "leaves divided into four, pointed lobes, and terminated by a shallow noteh, the extremity being nearly square and the middle rib ending abruptly as if cut off" Bigelow ; "leaves truncate at the top, four-lobed, resembling a saddle in shape" Loudon ; " folia truncata, sinuata, quadriloba" Bentham and Hooker; ${ }^{12}$ " leaves with two lateral lobes near the base, and two at the apex, which ap pears as if cut off abruptly by a broad shallow notch" Gray. ${ }^{13}$

There is no doubt that the diagnosis given by A. Michaux (l. $c$.$) is the$ only correct manner of describing this peculiar leaf, and, as has been shown above, it has been accepted by such authorities as Bentham, Hooker, and Gray. It is, however, to be remarked that Michaux's fourlobed leaf is properly to be understood as a lobed leaf with the summit wanting, or what he called "abscisso-truncatis (foliis)," while it is not correctly described by other authors, who have called the leaf three. lobed with the middle lobe "cut off." We have no leaf, as far as I know, either fossil or recent, of this genus in which we can find any complete middle lobe or anything like the entire leaf of the genus Magnolia, so closely allied to our Liriodendron; because I do not take the cotyle. dons into consideration. These are certainly entire, oblong, and taper. ing at both ends, distinctly but not sharply pointed at their summit,

${ }^{1}$ William Darlington: Flora Cestrica, 1853, p. 9.

${ }^{2}$ John Darby : Botany of the Southern States, 1855, p. 212.

${ }^{3}$ F. A. Michaux : North American Sylva, vol. II, 1865, p. 35.

${ }^{4}$ A. W. Chapman: Flora of the Southern United States, 1883, p. 14.

${ }^{5}$ A. Michaux: Flora Boreali-Americana, 1803, p. 326.

${ }^{6}$ Fr. Pursh : Flora Americæ septentrionalis, vol. II, 1816, p. 382.

${ }^{7}$ A. P. de Candolle: Prodromus syst. nat. regni. vegetab., vol. I, 1818, p. 461.

${ }^{8}$ William Barton: Compendium Floræ Philadelphicæ, 1818, p. 18.

${ }^{9} \mathrm{John}$ Torrey: Compendium of the flora of the Northern and Middle States, 1826, p. 221 .

1n J. Bigelow : Plants of Boston, 1840, p. 245.

"I I. C. Loudon: Trees and shrubs of Britain, 1875, p. 36.

12 Bentham aad Hooker: Genera plantarum, vol. I, 1867, p. 19.

${ }^{13}$ Asa Gray: Manual of Botany of the Northern United States, 5th ed., p. 50.

Proc. N. M. $90-2$ 
and show a considerable difference from the mature leaves. A drawing of one of the cotyledons is given on Plate IV, Fig. 1, and a germinating plantlet has been figured by Mirbel in his "Nouvelles recherches sur les caractères anatomiques et physiologiques qui distinguent les plantes monocotylédones des plantes dicotylédones."* But this circumstance that there is a difference between the cotyledons and the mature leaves does not seem to be of particular importance, when we are looking for the primeval leaf of any genus. We know well enough from the numerous contributions on the subject of the germination, how widely different the shape of the cotyledons can be from that of the mature leaves of the same plant, and I will merely call attention to the lobed cotyledons of Tilia, the entire ones of Acer, the Umbelliferce, etc.

As to the nervation of the mature leaf of the recent Liriodendron, this seems rather to show a four-lobed than a three-lobed leaf, or per. haps it would be better to say a pinnately-lobed than a palmately-lobed. The three-lobed leaf, for instance, of Sassafras, so exactly figured in Professor Ward's paper : "The paleontologic history of the genus Platanus," $†$ must probably always be considered as a really palmately-veined and lobed leaf, with the iwo lateral ribs of the lobes strongly developed and proceeding from the base of the midrib, in pairs. But we quite often find, on the other hand, small leaves of the genus Quercus with only one lateral lobe on each side, but such a leaf would never on that account be considered as three-lobed. And I propose to compare the leaf of Liriodendron with a lobed leaf of Quercus, on account of the nervation as shown on Plate IV, where several forms are figured of fullgrown leaves. We see on these leaves that the lateral ribs almost proceed in pairs to the lobes, but not at all from the base of the midrib. The leaf is really feather-veined, therefore pinnately-lobed, when lobes are present. Now as to the varieties of Liriodendron Tulipifera, but few have been mentioned and described, namely: " $\alpha$ acutiloba: lobis acutis acuminatisque, $\beta$ obtusiloba: lobis rotundato obtusissimis," both of A. Michaux, and finally a variety chinensis Hemsl. The two varieties, described by Mi haux, have been accepted by Pursh, De Candolle and Browne, though by the last named with a difference in the nomenclature ("acutifolia" instead of "acutiloba"), and with Loudon as author, but the description agrees perfectly with that given by Michaux. De Candolle has another variety "foliis quadri-lobis aut rarius subintegris ovatis apice truncato emarginatis $=L$. integrifolium hortul.," but this variety has been considered as identical with Michaux's obtusiloba by Loudon. Linné also made a variety " $\beta$. Tulipifera caroliniana foliis productioribus magis angulosis," which possibly may be the same as Michaux's variety acutiloba.

As to the variety chinensis, this was discovered in China by Dr.

* Aunales du Muséum d'hist. nat., XIII, 1809, Pl. VI.

† Proceedings U. S. National Museum, Vol. XI, 1888, Pl. XXI, 
Shearer and described as a new species, ${ }^{*}$ but has later been considered as merely a variety by Hemsley, $\dagger$ and it is very interesting, that we have here an Asiatic representative of Liriodendron, hitherto supposed to be confined to our country. Moore $(l . c$.$) remarks about this form,$ that it differs from the typical one in having the leaves more deeply lobed and being glaucous underneath. According to the description, given by Forbes and Hemsley $(l \cdot c$.$) , there has been observed a certain$ variation in the foliage of the same tree, siuce the leaves are either deeply lobed and the lobes very obtuse, or the lobes are very short and very acute. The authors, however, remark that these characters together with the size of the flower, which was a little different from that of the typical torm, might possibly be sufficient to rank it as an independent species, but the leaves do not give any distinctive character and the flowers differ only in size. We find, however, very little about the general variation in the foliage of the recent species, for the only author who mentions it is Curtis, $\ddagger$ who says: "They [the leaves] vary greatly in the division of their lobes." In the figure of the tree, given by F. A. Michaux (l.c.), there is, however, a leaf with two pairs of lobes, one of which has a short tooth at its base, while, as was stated, the most common form seems to be merely four-lobed; Bigelow § mentions, that "in the large leaves the two lower lobes are furnished with a tooth or additional lobe on their outside." Finally Heer || has given a very interesting note on the foliage of the recent Liriodendron as follows:

Die untersten Blätter der Z weige haben beim lebenden Tulpenbaum haüfig keinè seitlichen Lappen und siud vorn gegen die Ausbuchtung zugerundet, während die obern Z weigblätter die bekannten grossen, vorn zugespitzten Seitenlappen haben und der mittlere Lappen zu beiden Seiten der Ausrandung in spitzen Ecken endet. Von den ungelappten, grundständigen Blättern zu diesen scharf gelappten obern finden sich zahlreiche Uebergänge. Ich habe Taf. xxıII, Fig. 1, ein zweiggrundständiges, ungelapptes Blatt abgebildet, welches den ungelappten der Kreideart sehr ähnlich

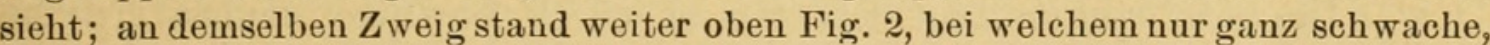
seitliche Lappen vorhanden sind, wie bei $L$. Meekii primcvum, während die meisten Blätter des Baumes die gewöhnliche, scharff gelappte Form zeigten. Der lebende Tulpenbaum zeigt daher dieselbe Polymorphie der Blätter, wie die Kreideart und steht dieser sehr nahe. Indessen sind die ungelappten Blätter der lebenden Art viel breiter und kürzer, manche fast kreisrund, am Grunde nicht in den Stiel hinablaufend ; der mittlere Lappen ist am Grund niemals verschmälert und die Lappen sind aussen in der Regel in eine Spitze auslaufend.

It seems therefore that Heer has understood the recent Liriodendron perhaps better than any one else!

If we now consider the figures on Plates IV to IX, all of which represent different stages of growth of Liriodendron Tulipifera, collected along

* Moore: Description of some new Phanerog, coll. by Dr. Shearer, at Kiukiang, China. (Journ. of Bot. n. s. IV, 1875, p. 225).

tF. B. Forbes and W. B. Hemsley: An enumeration of all the plants known from China proper, Formosa, Hainan, Corea, etc. (Journ. of Linn. Society, xxIII, No. 150 1886, p. 25).

$\ddagger$ Wm. Curtis: Botanical Magazine vir, 1794, p. 275 .

@ I. Bigelow: American Medical Botany 1818, p. 109.

॥ Oswald Heer: Flora fossilis arctica VI, 1882, p, 89. 
the shore of thePotomac and in the Smithsonian Park, we must wonder not a little that systematic authors have mentioned so few of these forms. We see here the most "insensible gradations" from the entire to the deeply-lobed leaves. We see the orbicular form in Fig. 5, the obcordate in Figs. 6, 7, and 8, the approximately bilobed in Figs. 16, 31, and 41, and the large variation in the upper margin of these small leaves, more or less notched, as for instance in Figs. 11, 13, 16, etc., or almost horizontal, as in Fig. 17, and, farther, how there is a weak, but quite distinct, attenuation of the blade into the petiole, as in Figs. 6 and 7. And if we examine the other forms with the lobes more or less developed, we shall find quite a large number of variations from Figs. 11, 15, and 17, to the more distinctly lobed leaves, as Figs. 18, 19, and 20, and finally the large leaves, Figs. 2, 3, and 4. We find here another kind of variation, in regard to the depth of the sinuses, merely shallow in Figs. 24 and 25, or very deep as in Figs. 23, 26, 27, 28, 29, and 30. And farther, as stated in the description of the small leaves, the upper margin varies very much in regard to its sinus, deep as in Figs. 22, 24, 39, and 40, or in a much smaller degree as in Figs. 3, 23, 25, 27, and 30. Finally, it must be remarked that the sinus at the base of the blade shows quite a large variation in its depth, but $I$ have not found a case in the larger leaves where the blade tapered into the petiole.

As to the varieties, I have obtained rich material from a single tree cultivated in the United States Botanical Garden under the name of "integrifolia," and I suppose this corresponds to Michaux's variety "obtusiloba." Leaves from this tree are figured on Plate vin, Figs. 32 to 37 , and these also differ among themselves, ranging from the small, obcordate leaf (Fig. 37) to the more obtuse one, Fig. 36, with the upper margin almost horizontal in contrast with the leaf, Fig. 37, where a deep depression is to be observed. The approximately roundish form, Fig. 33 , was the most common on this tree, of which, however, several leaves, as Fig. 32, showed two distinct teeth at the upper margin, corresponding to the upper lobes of the normally developed leaves; and moreover I observed not a few with an incipient dentation at the base and at the middle part of the blade, as shown in Fig. 34. The base showed here the same kind of variation as mentioned above in the typical forms. The other variety, "acutiloba" Michaux, is unknown to me, but it is possible that the small leaf, Fig. 23, and the larger ones, Figs. 26 to 30, show a similar form. They represent, however, not a variety, but merely a young state of the typical tree. The small leaf, figured on Plate vi, Fig. 23, has been taken from a plant, 1 foot high, of which the age was almost two years, and all the leaves on this specimen had this same shape. The larger leaves, Figs. 26 to 30 , belonged to a mere shrub, no more than 5 feet high, of which the leaves had either the same deeply lobed form, or, as shown in Fig. 31, the almost obcordate outline. It is to be supposed that this form may not be constant, and as the shrub gets older and attains a larger size the leaves will gradually acquire the 
normal shape. This is, however, only a supposition, but as mentioned above, the leaf shown in Fig. 23 was from a very young plant, of which I observed many in the same locality, all of which were similar.

If we look now at Plate Ix, which represents a part of the foliage of a shoot of the year and developed in the axil of the large leaf, Fig. 38, we shall see, as stated in the explanation of the plates, that Fig. 41 is the first and oldest one of this branch, after which followed a nearly normal four-lobed one, only a little smaller than usual; after this (Fig. 40), somewhat irregular, and still later two normal ones, both of the same shape as Fig. 39, which was the next youngest; the youngest leaf of this branch had again the same shape as that in Fig. 41 ; in short, the oldest and the youngest leaf on the same branch showed an entirely different form from the intermediate ones, of which the form has been taken as the normal one for our Liriodendron Tulipifera, viz: "the fourlobed leaf." It is to be pointed out that instead of the four-lobed leaves it is not uncommon to find leaves with six or even eight lobes, like teeth, as shown in Figs. 3 and 4. The fact that the oldest and youngest leaf on the same branch can differ so much from the other ones seems to be almost constant for the full-grown tree and especially on the lateral branches; it was at least the case with a very large number of branches, which I examined for that purpose. And if we examine very young specimens of our Liriodendron, only five months old, we shall certainly see a still greater variation in the young foliage. In some of these not less than five different forms were to be observed in six leaves! The first leaf after the cotyledons showed the shape as given on Plate v, Fig. 10, after this followed another one like Fig. 11, after this two, like Fig. 12, and then two four-lobed ones, the youngest of which showed the form as in Fig. 25, while the preceding was almost like Fig. 23. In general the first four or even five leaves on the very young Tulip tree have the same curious form as the oldest and youngest on the branches of the full-grown tree. This kind of variation in the foliage of many other trees and even in herbs is not uncommon, and it may certainly be considered as a constant character for many plants.

What then is the principal character of the recent Liriodendron-leaf, and what characters are to be looked for by the paleobotanists, when identifying fossil leaves, supposed to belong to the genus Liriodendron? There is nothing more striking in the leaf than the notch at its apex, which, as we have seen in the plates, is to be observed in all the leaves, excepting Fig. 5, both large and small, whether they are lobed or not. And if the paleobotanists do not find a completely preserved leaf, or at least the apex of it, then it will certainly be a question, whether or not they have the true Liriodendron before them, for I do not see any essential difference in the lobes alone nor in the partial nervation, which should be so characteristic as to guide the observer in identifying a fossil Liriodendron, if he had not the summit of the leaf. The lobes, considered by themselves, are not very different from those of many 
other plants, as for instance, species of Acer and Aralia, especially if the palmate nervation of these is not to be seen distinctly, which a small part of a lobe might not be able to show. And as to the smaller leaves, the obcordate ones, these are, when they occur as fossils, even more misleading. Leaves with the apex emarginate and of an obcordate form occur so often in the other families as the only typical form of the leaf or leaflet, that it would be more natural for the paleobotanist to think of such families rather than of such a genus as the Liriodendron. And their nervation is, in proportion to their size, rather indistinct and far from characteristic; they are regularly feather-veined.

But, still, as will be shown later, several fossil leaves of this obcordate shape have been identified as belonging to Liriodendron, whether correctiy or not is another question, but why should the ancient types not show at least a similar kind of variation, as does the recent one? There is a peculiar circumstance connected with Dr. Newberry's Liri. odendron oblongifolium, $L$. quercifolium, and $L$. simplex (l. c.). As the author remarks, the leaves of these three species are proportionally longer than those of the recent species. This seems to be characteristic of several of the other ancient forms, and is a point of great interest, especially because I believe, we may trace it in the recent leaf. There is, namely, in the leaf of Liriodendron Tulipifera a short point in the middle of the notch which is an elongation of the midrib, and I have observed this feature in all the leaves I have examined, of both old and young trees. This prolongation of the midrib might then show a rudiment of a longer midrib, that is, the leaf may formerly have been longer and then for some reason have decreased to its present size. It might, however, be objected to this supposition that it very often occurs, that such a point is to be found in leaves, and especially very commonly in the obcordate leaflets of many Leguminosa, where we are not entitled to presume a reduction in length of the leaf. I am well aware of this, but there is another fact that must be considered, namely, that the nervation of the leaflets, pointed and obcordate or with the apex of the blade notched as in Liriodendron, in Hamatoxylon, Colutea, and others, is somewhat different from that of such forms of the recent Tulip-tree. For even if the Liriodendron-leaves and the Leguminosa.leaflets are feather-veined, and generally show the same relatively coarse reticulation, yet while the nerves of the Leguminosa leaflets are almost parallel to each other, this is not always the case with Liriodendron. Just beneath the upper margin of the leaf of Liriodendron Tulipifera is to be observed one pair of very short and rather indistinct ribs, and these proceed almost horizontally from the midrib, while the other ones, at least in the smaller leaves, form an acute angle with the midrib. Might this pair of ribs not have shown an additional pair of lobes, when the leaf was longer, and are they not to be supposed to have always been present in the elongated midrib? This would at least be a great help to the correct understanding of the long leaves 
of the supposed Liriodendron oblongifolium, quercifolium, simplex, and others.

Now as regards the fossil leaves, belonging to the genus Liriodendron, all of them have been found either in the Cretaceous or in the Tertiary formation. They represent certainly several quite welldistinguished forms, but whether they represent a corresponding number of species is rather doubtful, at least, if we will compare them with the numerous variations, which, as stated above, occur even on the same tree, the only recent species of our flora. These supposed species are:

Liriodendron acuminatum Lesqx.

Liriodendron Celakovskii Velensk.

Liriodendron cruciforme Lesqx.

Liriodendron Gardneri Sap.

Liriodendron giganteum Lesqx.

Liriodendron Hauerii Ettings.

Liriodendron laramiense Ward.

Liriodendron Meekii Heer.

Liriodendion Meekii, var. genuina.

Liriodendron Meekii, var. Marcouana.

Liriodendron Meekii, var. mucronulata.

Liriodendron Meekii, var. obcordata.

Liriodendron Meekii, var. primava.

Liriodendron oblongifolium Newb.

Liriodendron pinnatifidum Lesqx.

Liriodendron Procaccinii, Ung.

Liriodendron Procaccinii, var. A, Helvetica.

Liriodendron Procaccinii, var. B, acutiloba.

Liriodendron Procaccinii, var. C, obtusiloba.

Liriodendron Procaccinii, var. C, (1) subattenuata.

Liriodendron Procaccinii, var. C, (2) rotundata.

Liriodendron Procaccinii, var. D, incisa.

Liriodendron quercifolium Newb.

Liriodendron semialatum Lesqx.

Liriodendron simplex Newb.

besides the Tertiary, considered as identical with our recent Liriodendron Tulipifera L.

We have here fourteen species, with, in all, eleven varieties enumerated of a genus, of which but one is still existing, properly indigenous in North America and China. We shall see later that, while some authors have not hesitated to consider the different forms as species, others have preferred to describe several of them as merely varieties. The geographical distributior of the Tulip-tree was certainly wide in the Cretaceous age, when it existed as far north as Greenland, and in the Tertiary formation it occurred in several parts of Europe from Iceland as far south as Italy. It is not strange then that a genus, scattered throughout many lands during two geological epochs, should have been represented by different forms, even specifically distinct. On the other hand, it must not be forgotten that there is very often to be observed a certain difference in the same plant when we compare its representatives from different countries with varied 
climates. I recall for instance the American variety of Castanea vesca, the variety populifolia of Betula alba, the variety Canadensis of Taxus baccata, and others, of which the typical forms are indigenous in Europe; and even among weeds we have several examples of that kind of variation, influenced by differences in climate and soil; as, for example, Alisma Plantago var. Americana, Veronica Americana but slightly different from the European species Beccabunga, the American varieties sinuata and integrifolia of Lycopus Europceus, and the numerous varieties of the Graminece from the most widely separate countries the world over.

And if the plant shows also a liability to variation in its foliage, as does our Tulip-tree, might not such kind of variation be brought about in a somewhat different manner, depending on climatological or terrestrial conditions? I do not think it unnatural to suppose so. But a variation in this manner or as the above mentioned of a more proper kind will not be considered as anything but a simple variation, at least not until the changes of the specific characters have increased so much after a very long space of time that the former variety becomes a species, a new type. And in the same manner the varieties might be supposed to belong to the original type, so that a number of apparently distinct forms must be reduced to one. Do not the numerous fossil Liriodendron, Sassafras, Liquidambar, Aralia, etc., favor that supposition? There is, if we will now regard the fossil leaves of Liriodendron, a great analogy with those of the living species, and the agreement is so striking, that it seems rather hard to distinguish most of them as true species, especially so when we are familiar with the recent forms. Therefore has Heer in his "Flora fossilis arctica," in the chapter entitled "Flora der Atanekerdluk" * preferred to consider some above. enumerated forms as merely varieties of the species $L$. Meekii, and of that reason, as he says (l. $c$.):

Ich bringe diese Formen zu einer Art, weil 1) so unmerkliche Uebergänge zwischen demselben stattfinden, dass keine sichern Grenzen zu ziehen sind; 2) dieselben Formen in der obern Kreide von Nebraska und Kansas vorkommen wie in Grönland, wie ein Blick Tafel xxın Fig, 3-6 zeigt, wo ich diese amerikanischen Blätter zur Vergleichung mit denen Grönlands abgebildet habe; 3) auch der lebende Tulpenbaum uns einen ähnlichen Formenkreis vou Blättern zeigt, etc., etc.

We can not but agree entirely with him, when we regard the series of leaves figured in his Flora fossilis arctica $(l . c$.$) on Plates XVIII,$ xxII, XxIII, and XLv. Among these leaves is Dr. Newberry's species primcevim, and it seems very curious that this author should so differ from Heer, since he says $(l . c .$, p. 4$)$ not only that this species is quite different from Heer's $L$. Meekii, but even that there are no connecting links between them. It is now to be remarked, that the mentioned leaves, figured by Heer, are from widely separated localities, namely the variety primceva from the Disco island in Greenland and from Kansas, the variety genuina from Nebraska, while the two others, $\dagger$

* Oswald Heer: Flora fossilis aretica, VI, Pars II, I882.

† Ibid., (l.c.), Plate xxII, Figs. 12 and 13. 
considered as identical with this, are found in the lower Atanekerdluk in Greenland. All the other varieties are either from this locality or from Asuk and Isunguak in Greenland, but nevertheless Heer did not find any reason for separating them, on the contrary, he found " insensible gradations" between them, and it seems that it is especially in regard to the understanding of the intergrading forms that Dr. Newberry does not agree with Heer.

What then, is the difference between Dr. Newberry's two leaves of his species $L$. primcevum and $L$. Meekii, both from Nebraska, when compared with those called L. Meekii var. primceva and genuina of Heer obtained from Greenland? I do not think there is any difference in the size as far as concerns the variety genuina, and in the other one, the variety primceva, the leaf from Greenland is somewhat defective, but shows, nevertheless, the emarginate summit and a little more than the half part of the blade, and this leaf does not differ more from Dr. Newberry's drawing than most of the variations I have figured from the living tree. Both of them show a somewhat rounded base, as if there was a tendency toward forming a basal lobe, and at the superior margin there is a distinct and roundish lobe. The nervation is entirely the same. The two forms primceva and genuina are by Heer united with the species Meekii, and it seems to be done so with the best reason; I would merely object to consider them as two different varieties, since the only difference is to be found in the number of lobes, there being two pairs in genuina and only one, or rather one pair of distinct lobes and another pair very obtuse, forming an expansion at the base of the blade of primceva. Do we not find a similar variation among some of the leaves from the living tree? I will merely call attention to a leaf, Plate VI, Figs. 19 and compare it with another one, Plate v, Fig. 11. It seems to me that we have here a very good analogy in regard to this question. If we examine the leaf on Plate $\mathrm{v}$, Fig. 17, which is from the same young tree as the first one, Fig. 19, we must certainly wonder that Dr. Newberry was unable to find any intergrading forms.

If we now consider the other varieties of $L$. Meekii, figured by Heer (l.c.), in his Plates XxII, xxIII, and XLV, we shall then again find a great mutual agreement. These leaves are almost entire or approximately obcordate, especially the variety obcordata, Plate xxIII, Fig. 4 (l. c.). The difference between these forms is very slight and limited, almost wholly, to the relative proportions of size. The variety obcordata shows this characteristic shape, while the leaves of Marcouana are longer and narrower, with the base of the blade tapering into the petiole. The third one, mucronulata, seems to be closely allied to the variety Marcouana, but shows a small point at the end of the midrib, a character, which has also been shown, however, in the leaf, Fig. 5, Plate XXII (l.c.), of Marcouana. This point seems to be analogous to the 
rudimentary prolongation of the midrib, as I have mentioned above and figured in the leaves of the living tree. It seems, then, as if we have the same fact here, that the leaves show an original longer-leaved type. But, owing to the shape of the notch in these three varieties, whatever this is, more or less deeply and sharply sinuate, Heer did not consider this circumstance as being of any essential importance, since he united a form as Fig. $13 a$ on Plate XLV (l.c.) of Marcouana with another one, Fig. 3 on Plate XxIII (l.c.), of the same variety, and he has certainly considered these two as identical with the best reason. For if we look at the small leaves, Figs. 6,10 , and 16 on Plate V, all borne on living trees, we shall find the same manner of variation. But I hardly consider these three forms as "varieties," iu consequence of the numerous gradation forms, which I have illustrated, and will again call attention to some of these figures. In regard to the relative proportions of length and breadth there is a series of gradations from Figs. 35 and 36 to Figs. 16 and 41, and we can see the same in regard to the depth of the notch at the apex of these leaves. I do not think it would be too hazardous to suppose Heer's varieties as merely forms, belonging to trees or branches of some different age, either very young or perhaps more mature. But Dr. Newberry objects even here, because Heer has regarded his $L$. primcevum as identical with such obcordate leaves of $L$. Meekii, as the last mentioned three varieties. Dr. Newberry remarks (l.c., p. 4), that "indeed the probabilities are against it, since no intermediate forms have been found, and none of the panduriform leaves of $L$. Meekii have been obtained from Greenland, where obovate, entire or emarginate leaves similar to those given the above names (Phyllites obcordatus and Leguminosites Marcouanus) do occur, and also many of the emarginate, oblong-ovoid, or lanceolate leaves, which I have called Liriodendron simplex."

It is now to be remembered, as mentioned before, that such obcordate leaves may occur, and indeed do commonly occur, together with leaves of the typical form on the same tree. I consider it rather as accidental that none of the panduriform leaves of $L$. Meekii have yet been discovered in Greenland, and it is strange that Doctor Newberry does not see any gradation forms in the Greenlandish leaves of L. Meekii, figured by Heer on Plate XxII, Figs. 12 and 13, and farther on Plate xviri, Fig. $4 c$ (l. $c$.).

Massalongo is another author with the same view in regard to the variation or rather the occurrence of different forms of a fossil Liriodendron species. We see in the Plates of his "Flora Senigalliese" * a series of leaves of a species which he has referred to $L$. Procaccinii Ung. This species, which was first described by Unger, $\dagger$ is characterized as follows: "Liriodendron foliis trilobis, lobo medio maximo truncato-emarginato, lobis lateralibus obtusis vel acutis integerrimis, nervis

* Massalongo: Flora Fossile del Senigalliese, 1859, p. 311.

†Fr. Unger: Genera et species plantarum fossilium, 1850 , p. 443. 
secundariis pinnatis subsimplicibus." Four varieties of this species have been enumerated by Massalongo:

A. L. Procaccinii v. helvetica.

B. L. Procaccinii v. acutiloba.

C. L. Procaccinii v. obtusiloba, $(\alpha)$ subattenuata, $(\beta)$ rotundata.

D. L. Procaccinii v. incisa.

The variety helvetica was first considered as a good species (L. helveticum) by Heer,* but after seeing the figures of $L$. Procaccinii, he agreed perfectly with Massalongo in referring it as a variety of this.

If we now turn to the drawings of this variety, $\dagger$ given by Heer, we shall see a very striking agreement with our recent species; indeed, it is rather difficult to find any essential differences. But the leaf, figured by Heer (Fig. 6) shows, moreover, that the blade tapers into the petiole in a somewhat larger degree than we find in the recent species, and this seems to be characteristic of some of the other varieties of L. Procaccinii. There is, however, in Heer's Uhrwelt der Schweiz (1879) a drawing of a leaf (Fig. 223), which has been identified as $L$. Procaccinii, where there is a distinct sinus at the inferior margin of the leaf instead of, as mentioned above, the blade tapered into the petiole. Heer's remark $\ddagger$ about this leaf from Iceland, collected by Japetus Steenstrup, is very interesting. He calls attention to the presence of five lobes, but does not think it correct, however, to separate it from the leaves of L. Procaccinii, collected by Senegaglia and Eriz, even if these do not show more than three lobes. He mentions the fact that the leaves of our recent Tulip-tree very often show five lobes or sometimes no lobes at all, therefore he does not consider the number of lobes as a character of much importance. Now, in regard to the systematic position of this leaf from Iceland, Heer has remarked not only that there is a great accordance between this and the other leaves of the same species from the continent, but even that these are clearly allied to the living species. There is another leaf considered as identic with L. Procaccinii, and figured by Heer in his Flora fossilis arctica, of which the margin seems to have been entire, without lobation, and if the identification be correct, since the fossil is very poor, $L$. Procaccinii has then shown the same variation as the recent, with the lobes wanting, and I should then compare this form with the leaves figured on Plate VIII, Figs. 33,36 , and 37 .

In regard to the other varieties of $L$. Procaccinii, described in Flora del Senigalliese, we see here on Plate vIr, Fig. 23, a leaf of acutiloba, the lobes of which are certainly very acute, but does not seem to differ from the variety Helvetica in any other respect, and might possibly correspond to Michaux's acutiloba of the recent species, at least, as a sim-

* Oswald Heer: Flora Tertiaria Helvetiæ, III, 1859, p. 195.

† Ibid., Vol. I, Plate Cvin, Figs. 6 and 6b, and Flora Fossilis Arctica I, 1868, Plate * xxviI, Fig. 5 .

$\ddagger$ Ibid., Flora Tert. Helv. III, 1859, p. 319 .

ઈIbid., Vol. I, 1868, Plate xxvi, Fig. $7 \mathrm{~b}$. 
ilar form, though with the exception that the blade tapers distinctly into the petiole in the leaf figured by Massalongo. And the next variety, obtusiloba, figured on Plate xxxix, Figs. 3 and $5 l$. c., shows again the same kind of variation which occurs so often in the foliage of $L$. Tulipi. fera, with the lobes more or less obtuse, an approach to the variety obtusiloba described by Michaux. The two subvarieties subattenuata and rotundata (Plate xxxix, Figs. 3 and 5 l.c.) are distinguished by their blades tapering into the petiole or not. The last variety, incisa (Plate xxxix, Figs. 4 and $6 l$. c.), shows a rather deep notch, but that is the only difference, and this seems to correspond to the leaves I have figured on Plates VI, Fig. 26, and Ix, Fig. 40. Furthermore, Ettingshausen* has described a species Liriodendron Hauerii, from a leaf of whicb, however, only the lower part is preserved and shows that the blade tapers into the petiole, and that there are two pairs of relatively strong lateral ribs, but without any lobes, since the margin of the leaf is entirely wanting. The author sees, nevertheless, in this poorly preserved fossil a difference not only from $L$. Tulipifera, but also from $L$. Procaccinii. Another species is L. Gardneri Sap., which has been mentioned by Saporta, $\dagger$ and this leaf does not seem to differ in any degree from the recent, at least not from the leaves figured on Plate VII, Figs. 26, $27,29,30$. Saporta compares this form with the above-mentioned variety chinensis, recently discovered in China. It is very interesting to see this leaf of $L$. Gardneri figured together with three other leaves, but representing $L$. Procaccinii from Iceland, Eriz, and Meximieux, since these four leaves illustrate, although in a small degree, the variation in the foliage of our living Tulip-tree. The same author has also, together with Marion, in their "Recherches sur les végétaux fossiles de Meximieux," $\ddagger$ described leaves of $L$. Procaccinii, some of which represent quite large leaves, especially Figs. 1 and $2(l . c$.$) , but unfortunately very$ defective, so that the lobes are not very distinct, but seem, however, to have been somewhat obtuse. The two leaves, Fig. 3 and $5(l . c$.), are, on the contrary, preserved very well, and show two very obtusely lobed leaves, and here is to be observed the rudimentary prolongation of the midrib. The last fossil European species of Liriodendron, L. Celakovskii, has been described by Velenovsky in his "Flora der Boehmischen Kreideformation," though with little success, since, according to the figure, it may never have belonged to any species of Liriodendron. It seems, therefore, quite curious to see the following remark of Velenovsky, concerning this leaf: "Von dem lebenden Amerikanischen L. Tulipifera L. unterscheidet sich L. Celakonskii durch die form, obwohl der Habitus und die Nervation in höchsten ('rade uebereinstimmt," because

* Constantin von Ettingshausen: Die fossile Flora des Tertiär-Beckens von Bilin, III, 1869, Plate XLI, Figs. 10 and $10 b$.

† G. de Saporta: Origive Paléontologique des arbres cultivés ou utilisés par l'homme, 1888, p. 266, Fig. 1.

‡ Archives dı Muséum d'histoire naturelle de Lyon, I, 1872, Pl. xxxıI, p. 271.

ई J. Velenovsky : Flora der Boehm. Kreideform. in Beiträge zur Paleontologie des Oesterreich-Ungarns und des Orient, III, 1883. 
the nervation of this leaf is so entirely different from what we have seen of the recent and fossil species of Liriodendron, since the leaf, figured by Velenovsky, shows a typical palmate nervation, which is never to be observed in the true geuus. It is a regular three-lobed leaf, of which the middle lobe is a little emarginate.

These fossil leaves of the European and Greenland Tulip.tree, which we have considered, have exhibited the same kind of variation in the leaves or foliage as our recent species. But it seems, as I have pointed out above, that the leaves of $L$. Procaccinii have been usually attenuated a little at the base, rather than showing the roundish form, which is the most frequent in the recent type, and this character might prob. ably be sufficient in distinguishing them as specifically differing from, although closely allied to, our recent species. Another character is, as has been observed by Heer, that some fruits found together with the leaves of the variety Helvetica, were much smaller and differed in several other respects from those of the recent type. We will now examine the American representatives of the ancestral forms of Liriodendron.

Several contributions have been published upon these ancient types by Lesquereux, Newberry, and Ward, and several species have been enumerated by these authors as belongiug to this genus. Léo Lesquereux has deseribed $L$. intermedium, $L$. giganteum, $L$. acuminatum, $L$. cruciforme, $L$. semialatum, and $L$. pinnatifidum, of which the last five have been mentioned in his "Report on the recent additions of fossil plants to the Museum collections." $\dagger$ The author, unfortunately, has figured only two of these six species, but his descriptions are sufficiently clear to give a correct idea of the shape of these leaves.

The first species, $L$. intermedium ( $l . c$. Pl. xx, Fig. 5), is a large leaf which seems to have been deeply four-lobed, with the characteristic notch at its apex, but the inferior part of the blade, as well as the outer portion of the lobes, are entirely wanting. It probably represented a form analogous to that shown on Plate VII, Figs. 26 to 30, but apparently with narrower lobes. The other figure, given by Lesquereux in his Cretaceous Flora, is of L. giganteum (l.c. Pl. XxII, Fig. 2), which shows only a mere lateral lobe of a very large leaf. He mentions, however, in his Peport $(l . c$.) that a beautiful entirely preserved leaf has been found of this species, of which the distance between the lower pair of lobes is indicated as being $20^{\mathrm{cm}}$. The lower lobes are oblong, obtuse, and very broad $\left(6^{\mathrm{cm}}\right)$, while the superior lobes are shorter, slightly turned upwards, and joining the lower ones in an obtuse sinus at a short distance of $2^{\mathrm{cm}}$ from the midrib. This description shows a form entirely differing from all those hitherto mentioned, and combines as a parallel the leaves figured on Plate VII, Figs. 26 to 30 , with the very obtusely lobed form figured on Plate VIII, Figs. 32 to 34 .

* Léo Lesquerenx: Coutributions to the fossil flora of the Western Territories. Part I. The Cretaceous Flora, 1874, p. 93.

† Bulletin of the Mus. of Compar. Zoology at Harvard College, vir, No. 6, 1881, p. 227. 
The next species, L. acuminatum, is a small-leaved form, of which the two pairs of lobes were only $1^{\mathrm{cm}}$ broad, linear, and acuminate, all curved upwards. It might represent a true species, if it did not belong to a young tree, for instance of $L$. intermedium, of which, as mentioned, the lobes were very narrow with a deep sinus, and there is a possibility that the lobes, or at least the upper one, have been directed up vards. A similar form has been described as characteristic of $L$. cruciforme, but the leaves of this species are large, the upper lobes broad and at right angles to the midrib; the lower lobes were narrow and turned upwards, a form that corresponds very closely to a leaf figured on Plate vII, Fig. 28. L. semialatum had merely one pair of short, rounded lobes at the base of the blade, and these were curved upwards and enlarged into an obovate or spathulate entire lamina.

I hardly think that we have any leaf in our recent species corresponding to this, unless the small, almost entire leaves, figured on Plate v, Figs. 7, 9, 10, 13, etc., might represent a form of an almost similar shape; but the author does not indicate any size of this peculiar leaf, nor any indication of the proportional length and width of the lobes. The last species, described by Lesquereux, is L. pinnatifidum, of which only a single leaf has been found, showing, as remarked by the author, the general facies of a Liriodendron, but subalternately trilobate on each side. The only character of this form should then be that the lobes were not opposite, and we might possibly have an abnormally developed leaf, similar to that, figured on Plate vi, Fig. 24, of which the lobes are to be called "approximately alternating." The top of the leaf was, however, broken, so that the true character of a Liriodendron, the notched apex, was wanting, and it is therefore a question as to whether the identification has been correct. It is interesting to see the manuer in which Lesquereux has considered these six species. It would seem, though, as if he were not unwilling to consider them merely as varieties, perhaps not of one, but of a few species. His remark that the local distribution of the leaves may be relied upon to give some directions for the separation of species is very precise; but, on the other hand, our knowledge of the very distribution of these types is proportionally far from sufficient. Some leaves have only been found in Nebraska and Minnesota, some others in Kansas, but that seems only fo show that they have occurred there; by no means that they have not existed in many other localities, and possibly even together. Another question is that there is a probability that we might consider them as local varieties of one or several species. It seems to me, that even if the species described by Lesquereux are mutualiy different, then we have seen above a similar variation in the foliage of but one species, and that the recent one. It may not be too hazardous to draw some conclusions from the living species, and suppose that these ancient American types have shown a liability to variation in the same degree as our recent form. We have, in regard to that conclusion, a leaf called Liriodendron laramiense by Professor Ward and found in the Laramie 
Formation, the age of which has been considered as Upper Cretaceous. This leaf is figured in Professor Ward's "Types of the Laramie Flora."* and shows, even if the upper part is wanting, a form so much like the leaves I have figured on Plate VIII, Figs. 36 and 37, that I do not see any difference at all, as far as concerns the preserved part of it. The margin seems to have been entire and the nervation accords with this variety in all details.

Three other species have been described by Dr. Newberry (l. c.), namely: L. oblongifolium, $L$. quercifolium, and $L$. simplex, collected in the Amboy clays-Middle Cretaceous - of New Jersey and Long Island. These three forms are large leaves, being deeply-lobed in $L$. quercifolium, shortly lobed in L. oblongifolium, and almost entire margined in $L$. simplex. The two first mentioned show a variation analogous to the recent form and the last one is very much like the leaves of very young trees of our living species. L. oblongifolium was a very large-leaved form, of which the leaves were 6 to 8 inches long and 4 to 5 inches wide, and, according to the figure in Dr. Newberry's paper, Plate LXI, Fig. 1, there are four teeth or very short, acute lobes on one side of the leaf. The other half is broken, but shows two lobes which are not quite opposite those on the other side. This leaf has, then, been subalternately lobed or rather dentate. There is a distinct notch at the apex of the blade, and the base does not taper into the petiole, so that it accords very well with the leaf of a true Liriodendron, but it may be a question whether to consider it as a species or merely as a variety. It looks so very much like the variety from the United States Botanical Garden that although it is far from my intention to connect it with the recent type, I can but regard it as a variety of a form with more deeply lobed leaves, or in any case as something corresponding to our recent form. The leaf, figured on Plate viII, Fig. 34, shows a somewhat similar shape having three teeth, which are a little shorter than those of L. oblongifolium. In regard to the occurrence of this species, it has been found together with $L$. quercifolium, figured by Dr. Newberry $(l . c$., Plate LXII, Fig. 1), and this seems to be a very interesting circumstance. This species, L. quercifolium, has four pairs of long acuminate lobes, and the size of the leaf was almost the same as indicated for L.oblongifolium, but did not attain the length nor width of larger specimens of this. That is the same case that $I$ have observed in the recent typical form and the variety from the Botanical Garden, and it is possible that we have, to support this conclusion, an analogous variation before us, rather than two distinct species. It may not be denied, if we will compare them with the above-mentioned leaves of the recent type and the variety, that there is a very good accordance, and in that manner, that $L$. quercifolium should be the species and $L$. oblongifolium its variety. But it is, on the other hand, difficult to say whether Dr. Newberry's third species, "simplex," is a Liriodendron or not, at least according to the figures given by him $(l . c$.$) , since the nervation is so entirely differ-$

*Bull, of U. S. Geol. Survey, 1887, p. 102, Plate XLviII, Fig. 2. 
ent from that of the true Liriodendron-leaves of the same relative shape. I am inclined to believe that the drawings have not been made with sufficient care and that the leaves, merely in regard to the outlines alone, belonged to a large-leaved Liriodendron. They may not represent a true species but may be considered as leaves of younger trees of some species with which they have been found associated, for example L. quercifolium. We should, then, have a better illustration of one of the ancestors of the Tulip-tree, the typical form, represented by L. quercifolium, a variety "oblongifolium," and finally the same kind of variation in the foliage as has been described in our recent tree, represented by the form "simplex."

We have now regarded a series of fossil leaves which have been identified as having belonged to species different from the recent, but it seems, however, as if the true Liriodendron Tulipifera had existed before in the Pliocene formation. A few years ago some leaves of a Liriodendron were discovered in the Altai Mountains, which have been described by Schmalhausen* as identical with our recent species, and a figure of one of these leaves shows the superior margin with the shallow notch and a lobe, just as it is in the typical form of $L$. Tulipifera. It is a discovery of great interest, since there is but a very small difference between this leaf and Liriodendron Procaccinii var. helvetica from the Tertiary formation of Switzerland and Iceland.

If we will now consider these fossil leaves by themselves we shall see that the majority are lobed with acute or obtuse lobes and that there is on the other hand a number of which the lobes were probably wanting, as it seems according to the defective fossils, or the leaves show a more or less obcordate shape. They may be arranged in three groups according to these characters, namely :

I. Leaf lobed.

A. Lobes acute.

L. acuminatum Lesqx.

L. cruciforme Lesqx.

L. Gardneri Sap.

L. intermedium Lesqx.

L. oblongifolium Newb.

L. pinnatifidum Lesqx.?

L. Procaccinii var. Helvetica Heer.

L. Procaccinii var. acutiloba Massal.

L. quercifolium Newb.

L. Tulipifera $\mathrm{L}$.

B. Lobes obtuse.

L. giganteum Lesqx.

L. Meekii var. genuina Heer.

L. Meekii var. primava (Newb.) Heer.

L. Procaccinii var. incisa Massal.

L. Procaccinii var. obtusiloba $\left\{\begin{array}{l}\text { rotundata } \\ \text { attenuata }\end{array}\right\}$ Massal.

L. semialatum Lesqx.

* Ueber tertiære Pflanzen aus dem Thale des Flusses Buchtorma am Fusse des Altaigebirges. Palæontographica, xxxıI, 1887. 
II. Leaf apparently ovate without lobation.

L. laramiense Ward.

L. Procaccinii Heer (Pl. xxvi, Fig. 7 b, l. c.)

III. Leaf obcordate, more or less oblong.

A. With rudimentary prolongation of the midrib.

L. Meekii var. mucronulata Heer.

B. Without any prolongation of the midrib.

L. Meekii var. Marcouana Heer.

L. Meekii var. primava (Newb.) Heer.

L. Meekii var. obcordata Heer.

L. Procaccinii Ung.

L. simplex Newb.

(Leaf, of which the outlines are unknown: L. Hauerii Ettingsh.)

There is, however, another character besides the above mentioned, and this is whether the base of the blade is horizontal or tapering into the petiole, the last of which seems to be especially characteristic of the obcordate leaves, but also varies. We find namely in L. Meekii, var. mucronulata one leaf with the true obcordate shape, while another one has the inferior margin of the blade distinctly horizontal, but in all the other ones of Group III the blade tapers into the petiole. We find the same kind of variation in the lobed leaves, as, for instance, the varieties Helvetica and acutiloba of $L$.Procaccinii, and farther, the varieties primava and genuina of L. Meekii, while the base of the blade is almost horizontal in the recent species. This fact does not seem to speak in any absolute favor of a correct identification of the fossil leaves with such a distinct tapering form of the blade into the petiole, and as pointed out above there is good reason for considering some of the obcordate leaves as belonging to plants of a quite different family, namely, if we compare them with leaflets of the Leguminosce. But we must then see the articulation, and this very probably has been indistinct, since there is no trace to be observed on any of the numerous figares given of these fossil leaves.

What form then, may be supposed as the original one of the Liriodendron-leaf? I am inclined to think that we can conclude nothing positively in regard to the hitherto known fossil leaves identified as Liriodendron, and it is especially the presence of the rudimentary prolongation of the midrib, observed not only in the recent species but also in some of the fossil leaves, which gives us the greatest difficulty, because we are entitled to conclude from this circumstance that the leaf has not only been longer and with a larger number of lobes, but also with an apex corresponding in size and shape to the lobes. There is, as it seems to me, the apparently entire leaf of $L$. laramiense and some of the obcordate leaves of the other species, which are of the greatest interest. We have but to elongate the midrib of these a little and we will obtain either an obtuse or acuminate leaf, corresponding to the genus Magnolia, and I myself am not unwilling to suppose such a form as proper to the ancient type of the Tulip-tree. The identification of

Proc. N. M. $90--3$ 
these Magnolia-like leaves would certainly be very difficult or perhap even impossible, and I do not think it too hazardous to suggest tha some of these leaves have already been discovered, but identified an described as Magnolia or possibly referred to other genera. U. s. National Museum, November, 1889.

\section{EXPLANATION OF PLATES.}

\section{Liriodendron Tulipifera L.}

\section{Plate IV.}

Fig. 1. A cotyledon, four times natural size, reduced one-third.

2. A typical leaf of an old tree, two-thiris natural size.

3. A typical leaf of the same tree, two-thirds natural size.

4. A typical leaf of the same tree, two-thirds natural size.

Plate V.

\section{(All natural size.)}

Fig. 5. Leaf of a plant, five months old; No. 1 after the cotyledons.

6. Leaf of a plant, five months old; the youngest one.

7. Leaf of a plant, five months old; No. 3 after the cotyledons.

8. Leaf of a plant, five months old; No. 1 after the cotyledons.

9. Leaf of a plant, five months old; No. 3 after the cotyledons.

10. Leaf of a plant, five months old; No. 1 after the cotyledons.

11. Leaf of a plant, five months old; No. 3 after the cotyledons.

12. Leaf of a plaut, five months old; No. 2 after the cotyledons.

13. Leaf of a plant, five months old; No. 4 after the cotyledons.

14. Leaf of a plant, five months old; No. 4 after the cotyledons.

15. Leaf of a plant, five months old; No. 2 after the cotyledons.

16. Leaf of a plant, five months old; No. 4 after the cotyledons.

17. Leaf of a plant, five months old; No. 3 after the cotyledons. The leaves Figs. 7, 14, and 16 are from the same plant. The leaves Figs. 10 and 11 are from the same plant. The leaves Figs. 12 and 17 are from the same plant.

\section{Plate VI.}

\section{(All natural size.)}

Fig. 18. Leaf of a plant, five months old ; No. 4 after the cotyledons.

19. Leaf of a plant, five months old; No. 4 after the cotyledons.

20. Leaf of a plant, five months old; No. 5 after the cotyledons.

21. Leaf of a plant, five months old; No. 6 after the cotyledons.

22. Leaf, the next oldest one, of a branch from an old tree.

23. Leaf, the next youngest, of a plant, two years old.

24. Leaf, the youngest one, of a branch from an old tree.

25. Leaf, the next oldest one, of a branch from an old tree. The leaves Figs. 9 and 18 are from the same plant.

The leaves Figs. 15 and 19 are from the same plant.

The leaves Figs. 22, 24, and 25 are from the same tree. 


\section{Plate VII.}

(One-third natural size.)

Fig. 26. Leaf taken from a mere shrub.

27. Leaf taken from the same shrub.

28. Leaf taken from the same shrub.

29. Leaf taken from the same shrub.

30. Leaf taken from the same shrub.

31. Leaf the oldest one, of a branch of the same shrub.

The leaves Figs. 26 to 31 have all been taken from the same shrub in the wood on the shore of the Potomac.

\section{Plate VIII. \\ (One-third natural size.)}

Fig. 32. Leaf of a tree in the Botanical Garden, labeled var. integrifolia.

33. Leaf of the same tree.

34. Leaf of the same tree.

35. Leaf, the oldest one of a branch from the same tree.

36. Leaf, the oldest one of a branch from the same tree.

37. Leaf, the oldest one of a branch from the same tree.

\section{Plate IX.}

\section{(Two-thirds natural size.)}

Fig. 33. Leaf, taken from an old tree. In the axil of this leaf had been developed a shoot, which carried the following leaves:

39. The next youngest one.

40. The third one after Fig. 41.

41. The oldest one. 


\section{$2 \mathrm{BHL}$ Biodiversity Heritage Library}

Holm, Theodor. 1890. "Notes on the leaves of Liriodendron." Proceedings of the United States National Museum 13(794), 15-35.

https://doi.org/10.5479/si.00963801.13-794.15.

View This Item Online: https://www.biodiversitylibrary.org/item/53445

DOI: https://doi.org/10.5479/si.00963801.13-794.15

Permalink: $\underline{\text { https://www.biodiversitylibrary.org/partpdf/52023 }}$

\section{Holding Institution}

Smithsonian Libraries

\section{Sponsored by}

Smithsonian

\section{Copyright \& Reuse}

Copyright Status: Public domain. The BHL considers that this work is no longer under copyright protection.

This document was created from content at the Biodiversity Heritage Library, the world's largest open access digital library for biodiversity literature and archives. Visit BHL at https://www.biodiversitylibrary.org. 